\title{
Effects of mineral amendments on trace elements leaching from pre-treated marine sediment after simulated rainfall events ${ }^{\text {tr }}$
}

\author{
C. Hurel ${ }^{\mathrm{a},{ }^{*}}$, M. Taneez ${ }^{\mathrm{b}}$, A. Volpi Ghirardini ${ }^{\mathrm{c}}$, G. Libralato ${ }^{\mathrm{c}, \mathrm{d}}$ \\ a Laboratoire de Physique de la Matière Condensée, UMR CNRS 7336, Université de Nice Sophia Antipolis, 28 avenue Valrose, 06108 Nice Cedex 2, France \\ ${ }^{\mathrm{b}}$ Laboratoire Ecosystèmes Marins et réponse aux stress (ECOMERS), FRE CNRS 3729, Université de Nice Sophia Antipolis, 28 avenue Valrose, 06108 Nice \\ Cedex 2, France \\ ${ }^{c}$ Department of Environmental Sciences, Informatics and Statistics, University Ca' Foscari Venice, Via Torino 155, 30172 Venezia-Mestre, Italy \\ ${ }^{\mathrm{d}}$ Department of Biology, University of Naples Federico II, Complesso Universitario di Monte S. Angelo, Via Cinthia ed. 7, 80126 Naples, Italy
}

\section{A R T I C L E I N F O}

\section{Article history:}

Received 12 May 2016

Received in revised form

23 September 2016

Accepted 23 September 2016

Available online 1 October 2016

\section{Keywords:}

Dredged marine sediments

Trace elements

Mineral amendments

Stabilization

Red mud

\begin{abstract}
A B S T R A C T
Bauxite extraction by-products (red mud) were used to evaluate their potential ability to stabilize trace elements from dredged and aerated/humidified marine sediment. The investigated by-products were: bauxaline ${ }^{\circledR}(\mathrm{BX})$ that is a press-filtered red mud; bauxsol ${ }^{\mathrm{TM}}(\mathrm{BS})$ that is a press-filtered red mud previously washed with excess of seawater, and gypsum neutralized bauxaline ${ }^{\circledR}$ (GBX). These materials were separately mixed to dredged composted sediment sample considering $5 \%$ and $20 \%$ sediment: stabilizer ratios. For pilot experiments, rainfall events were regularly simulated for 3 months. Concentrations of As, $\mathrm{Mo}, \mathrm{Cd}, \mathrm{Cr}, \mathrm{Zn}, \mathrm{Cu}$, and $\mathrm{Ni}$ were analyzed in collected leachates as well as toxicity. Results showed that $\mathrm{Cd}$, $\mathrm{Mo}, \mathrm{Zn}$, and $\mathrm{Cu}$ were efficiently stabilized in the solid matrix when $20 \%$ of BX, BS, and GBX was applied. Consequently, toxicity of leachates was lower than for the untreated sediment, meaning that contaminants mobility was reduced. A 5\% GBX was also efficient for $\mathrm{Mo}, \mathrm{Zn}$ and $\mathrm{Cu}$ stabilization. In all scenarios, As stabilization was not improved. Compared to all other monitored elements, Mo mobility seemed to depend upon temperature-humidity conditions during pilot experiments suggesting the need of further investigations.
\end{abstract}

() 2016 Elsevier Ltd. All rights reserved.

\section{Introduction}

In the mid-1960s, environmental concerns arose in most European countries and national governments started to be more active in their attempts to monitor and control environmental pollution. Major focus was devoted to develop and implement environmental quality guidelines in policies and regulations (Van Wezel, 1999). Special attention was dedicated to the disposal of sediment resulting from dredging activities of port channels and seaways in order to maintain maritime navigation. Yearly, in France approximately $50 \times 10^{6} \mathrm{~m}^{3}$ of sediment are dredged out (Alzieu, 1999; Duclay et al., 2010). Recent studies have shown that the Mediterranean coastal sediment can be heavily contaminated due to industrial, port and anthropogenic activities (Andral et al., 2004; Tessier et al., 2011; Pougnet et al., 2014). Sediment pollution is

\footnotetext{
This paper has been recommended for acceptance by Maria Cristina Fossi.

* Corresponding author.

E-mail address: charlotte.hurel@unice.fr (C. Hurel).
}

associated with potential economic, social and environmental problems (Eggleton and Thomas, 2004; Förstner, 2006; Arizzi Novelli et al., 2006; Libralato et al., 2008; Lofrano et al., 2016a). The management of dredged sediment must comply with the World London Convention for the prevention of marine pollution as a result of waste dumping (Duncan, 1973), and the OSPAR convention for the protection of marine natural environments of the North-East Atlantic (OSPAR, 1992). Sediment monitoring can be carried out through physico-chemical analyses and toxicity testing that became a widespread regulatory requirement of potential environmental hazards helping in decision-making about contaminated sediment (Prato et al., 2015). In France, dredged materials are managed considering quality guidelines including two regulatory levels (N1 and N2) defined on the basis of contaminant concentrations (trace elements and PCBs) in sediment. When the concentration of pollutants is $<\mathrm{N} 1$, sediment is classified as lightly contaminated with no significant impacts on the environment. Sediment is considered as contaminated if pollutants are between $\mathrm{N} 1$ and N2 levels thus dredging impacts must be investigated specifically. Highly contaminated sediment are 
ranked $>$ N2. Toxicity testing is necessary in the case of contaminated and highly contaminated sediment to assess their potential environmental impact. To facilitate sediment risk assessment, several toxicity tests have been proposed such as bivalve embryotoxicity and Microtox ${ }^{\circledR}$ assays (Alzieu and Quiniou, 2001; Libralato et al., 2008). When the pollutant concentrations found in sediment is $>\mathrm{N} 2$, direct landfill is prohibited, and contaminants must be immobilized before dumping on land (Alzieu, 2005). For this reason, stabilization/solidification techniques involving the use of mineral amendments were found to be cost effective and promising treatments. They amplify the rate of stabilization by enhancing adsorption, precipitation and complexation reactions onto soil or sediment components (Peng et al., 2009;Scanferla et al., 2009). The most studied mineral amendments are phosphate materials, alumino-silicates (clay and zeolites), alkaline materials and iron bearing compounds (zero valent iron, goethite, hematite, and ferrihydrite). Alumino-silicates and iron-based materials are able to immobilize the highest number of pollutants (Kumpiene et al., 2008; Komarek et al., 2013; Mamindy-Pajany et al., 2013).

In a previous work, sediment toxicity after stabilization with mineral amendments was evaluated using Microtox ${ }^{\circledR}$ solid phase test which was widely used to evaluate the toxicity of polluted sediments (Doherty, 2001; Onorati and Mecozzi, 2004; GonzalezMerchan et al., 2014). Dredged sediment samples were first aerated/humidified for 4 months to biologically reduce the organic contamination (i.e. pre-treatment), and then stabilized with three commercial mineral additives: i) hematite; ii) zerovalent iron; and iii) zeolite. Results showed that all mineral additives acted as stabilizing agents decreasing the levels of dissolved metal concentrations and sediment toxicity, but their employ could be expensive due to the use of commercial products (Mamindy-Pajany et al., 2012). Amongst the non-commercial potential additives, red mud (RM) could represent an interesting solution. RM is a very alkaline by-product obtained after bauxite ore extraction (according to Bayer process) for aluminum ( $\mathrm{Al}$ ) production. It is produced in huge amounts since 1 ton of extracted $\mathrm{Al}$ generates in $0.5-1$ ton of $\mathrm{RM}$ (Genç et al., 2003). It is characterized by the presence of Fe- and Aloxy-hydroxides making this by-product an interesting material to be reused for metals or organics removal, for hydrogenation, or as an additive for cement and brick industries (Singh et al., 1993; Llano et al., 1994; Alvarez et al., 1995; Peng et al., 2005). Considering the amount of the produced RM and its adsorption properties, research activities on its potential reuse as a cost effective and safe material for environmental purposes are of great interest for Al producers. Actually, less than $3 \%$ of bauxite residues produced annually is used in a productive way (Evans, 2016).

On the basis of Mamindy-Pajany et al. (2012), the aim of this research study was to investigate the use of RM as a low cost mineral amendment in ex situ off site stabilization of trace inorganics in pre-treated dredged sediment samples. Pilot scale experiments were carried out for 3 months considering various RM formulations (i) bauxaline ${ }^{\circledR}(\mathrm{BX})$; ii) bauxsol ${ }^{\mathrm{TM}}$ (BS); iii) bauxaline ${ }^{\circledR}$ neutralized by the addition of gypsum (GBX). BX, BS and GBX were mixed with dredged sediment including two "additive: sediment" ratios: i) $5 \%$ and ii) $20 \%$.Treated sediments were regularly exposed to simulated rainfall events and leachates were collected and measured in order to evaluate its feasibility to stabilize sediment inorganic pollutants to be landfilled.

\section{Material and methods}

\subsection{Sample collection}

Sediment samples resulting from dredging activity in the Toulon French Navy harbor (Mediterranean Sea) were considered. After dredging, sediment was kept on land and regularly aerated/humidified for 4 months by port authority. This procedure consisted in i) sediment mixing once a week promoting microbial consortia growth and, thus, biological degradation of contaminants as well as lowering salt and organic matter content, and ii) sediment humidification with tap water. Two sub-samples of this sediment were collected to carry out laboratory scale experimental activity. Sediment was already fully characterized (Mamindy-Pajany, 2010). Data from X-ray diffraction (XRD) of dredged sediment indicated the presence of calcite, feldspar, quartz and illite minerals. Mineralogical analysis of the fraction $<2 \mu$ m showed that sediment clay fraction contained illite (73\%), kaolinite (19\%) and smectite (8\%) (Mamindy Pajany et al., 2010). According to Table 1, sediment is highly contaminated by inorganics and can be classified as $>\mathrm{N} 2$ level for inorganic pollutants requiring ex situ off site management (Taneez et al., 2015, 2016).

\subsection{Industrial by-products used as mineral amendment}

We used an industrial by-product from bauxite extraction as mineral amendment to stabilize trace elements in marine dredged sediment. Bauxite by-product, commonly known as RM, is generated during alumina production from bauxite ore. RM is highly alkaline ( $\mathrm{pH} 10-13)$, reddish brown in color with a fine particle size distribution containing $\mathrm{Al}, \mathrm{Fe}, \mathrm{Si}$, andTi oxides and hydroxides (Nadaroglu et al., 2010).

ALTEO plant (Gardanne, Bouches-du-Rhône, France) that supplies specialty alumina since 1893 from bauxite, provided RM for this study. Press-filtered raw RM is commercially known as bauxaline ${ }^{\circledR}$ (BX) and its composition is given in Table 2. Despite its interesting mineral composition, BX use has been hindered because of its high alkalinity. To overcome this limitation, neutralization treatments have been investigated. One of these treatments consists in promoting the formation of hydrotalcite, calcite and brucite from RM by precipitation of alkaline species from seawater (i.e. soluble $\mathrm{Ca}^{2+}$ and $\mathrm{Mg}^{2+}$ ). Using excess seawater resulted in neutralization of RM to approximately pH 8.5 (Burke et al., 2013; Kirwan et al., 2013). In this study, the resulting neutralized RM was bauxsolTM (BS) (Table 2). Another possible treatment consists in $\mathrm{pH}$ neutralization by gypsum addition $\left(\mathrm{CaSO}_{4} \cdot 2 \mathrm{H}_{2} \mathrm{O}\right)$ that is a soluble $\mathrm{Ca}^{2+}$ source expected to buffer BX alkalinity similarly to seawater effect (Kirwan et al., 2013). The resulting neutralized BX was called "gypsum neutralized BX" (GBX) (Table 2). For this study, BX and BS were provided by ALTEO plant (Gardanne, France), and GBX by INERIS Méditerranée (France).

\subsection{Experimental setup}

Experiments lasted 3 months and were conducted in Nice

Table 1

Total content of elements in sediment sub-samples (ND: not defined) (dark grey cells: concentration $>$ N2). Data for $1^{\text {st }}$ sediment sub-sample are from (Taneez et al., 2015); and for $2^{\text {nd }}$ sediment sub-sample from (Taneez et al., 2016). Regulatory levels are from (Alzieu and Quiniou, 2001)and (Alzieu, 2005).

\begin{tabular}{lllll}
\hline Elements & $\begin{array}{l}1^{\text {st }} \text { sediment } \\
\text { sub-sample } \\
(\mathrm{mg} / \mathrm{kg})\end{array}$ & $\begin{array}{l}2^{\text {nd }} \text { sediment } \\
\text { sub-sample } \\
(\mathrm{mg} / \mathrm{kg})\end{array}$ & $\begin{array}{l}\text { French } \\
\text { regulatory } \\
\text { levels }(\mathrm{mg} / \mathrm{kg})\end{array}$ \\
\cline { 5 - 5 } & 150 & 201 & $\mathrm{~N} 1$ & $\mathrm{~N} 2$ \\
\hline $\mathrm{As}$ & 4.7 & 4.8 & 25 & 50 \\
$\mathrm{Cd}$ & 1721 & 1881 & 1.2 & 2.4 \\
$\mathrm{Cu}$ & 9.1 & 7.4 & 45 & 90 \\
$\mathrm{Mo}$ & 27 & 21 & $\mathrm{ND}$ & $\mathrm{ND}$ \\
$\mathrm{Ni}$ & 1869 & 3069 & 37 & 74 \\
$\mathrm{Zn}$ & 59 & 43 & 276 & 552 \\
$\mathrm{Cr}$ & & & 90 & 180 \\
\hline
\end{tabular}


Table 2

Composition of bauxaline ${ }^{\circledR}$, bauxsol ${ }^{\mathrm{TM}}$ and neutralized bauxaline ${ }^{\circledR} ; \mathrm{RM}=$ red mud.

\begin{tabular}{|c|c|c|c|c|c|}
\hline Material & Acronym & $\mathrm{pH}$ & Composition & Trace elements (mg/kg) & Properties \\
\hline Bauxaline $^{\circledR}$ & $\mathrm{BX}$ & 10.6 & $\begin{array}{l}\mathrm{Al}_{2} \mathrm{O}_{3}(14 \%) \\
\mathrm{Fe}_{2} \mathrm{O}_{3}(50 \%) \\
\mathrm{TiO}_{2}(11.5 \%) \\
\mathrm{SiO}_{2}(6 \%) \\
\mathrm{CaO}(5.5 \%) \\
\mathrm{Na}_{2} \mathrm{O}(3.5 \%)\end{array}$ & $\begin{array}{l}\text { As }<\text { DL } \\
\text { Cd: } 0.69 \\
\text { Cu: } 20.2 \\
\text { Mo }<\text { DL } \\
\text { Ni: } 7.00 \\
\text { Zn: } 13.0 \\
\text { Cr: } 1864 \\
\text { V: } 942\end{array}$ & 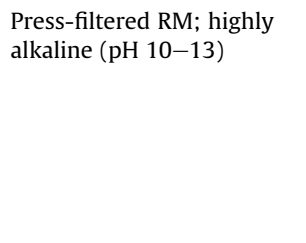 \\
\hline Bauxsol & BS & 9.4 & $\begin{array}{l}\mathrm{Al}_{2} \mathrm{O}_{3}(14 \%) \\
\mathrm{Fe}_{2} \mathrm{O}_{3}(50 \%) \\
\mathrm{TiO}_{2}(11.5 \%) \\
\mathrm{SiO}_{2}(6 \%) \\
\mathrm{CaO}(5.5 \%) \\
\mathrm{Na}_{2} \mathrm{O}(3.5 \%)\end{array}$ & $\begin{array}{l}\text { As }<\text { DL } \\
\text { Cd: } 0.58 \\
\text { Cu: } 14.4 \\
\text { Mo }<\text { DL } \\
\text { Ni: } 7.15 \\
\text { Zn: } 7.03 \\
\text { Cr: } 1579 \\
\text { V:1051 }\end{array}$ & $\begin{array}{l}\text { RM with excess seawater to } \\
\text { lower alkalinity }\end{array}$ \\
\hline
\end{tabular}

(French Riviera, France) in a covered area. For each experiment one replicate was performed due to the limited amount of dredged sediment available for this study. The first run (ES1 -first sediment sub-sample) was carried out from March 2013 to June 2013, and the second one from April 2014 to July 2014 (ES2-second sediment subsample). Experiments were carried out in wooden boxes $(40 \times 40 \times 20 \mathrm{~cm})$. The inner surface was covered with low porosity geotextile to limit the loss of fine particles and the bottom presented a plastic square mesh $(0.5 \mathrm{~cm} \times 0.5 \mathrm{~cm})$ allowing leaching water passing through. For ES1, 3 boxes were used, while 5 boxes were necessary for ES2. An amount of $6 \mathrm{~kg}$ of sediment was placed into each box. During ES1, 5\% of BX and BS were added to sediment and manually homogenized. During ES2, 5\% of GBX and 20\% of BX, $\mathrm{BS}$ and GBX were added to sediment and manually homogenized. Both ES1 and ES2 included control sediment made of untreated sediment (Table 1). After treatment administration to sediment samples, rainfall events were simulated pouring $2 \mathrm{~L}$ of tap water (72.05 mg/L of $\mathrm{Ca}^{2+}$; $9.79 \mathrm{mg} / \mathrm{L}$ of $\mathrm{Mg}^{2+}$; $3.35 \mathrm{mg} / \mathrm{L}$ of $\mathrm{NO}_{3}^{-}$; $10.65 \mathrm{mg} / \mathrm{L}$ of $\mathrm{Na}^{+} ; 1.35 \mathrm{mg} / \mathrm{L}$ of $\mathrm{K}^{+} ; 10.5 \mathrm{mg} / \mathrm{L}$ of Cl${ }^{-} ; 116.05 \mathrm{mg} / \mathrm{L}$ of $\mathrm{SO}_{4}^{2-}$; $175 \mu \mathrm{g} / \mathrm{L}$ of $\mathrm{F}^{-}$) according to the following steps: 1) $1 \mathrm{~L}$ of tap water was sprayed homogeneously on sediment surface; 2) sediment was aerated manually using a garden shovel; and 3) $1 \mathrm{~L}$ of water was sprayed. This procedure was repeated every two days during the first week and every 3 days during the second week. Then, it was repeated once a week until the end of the experiment. Each spraying procedure was equivalent to $12.5 \mathrm{~mm}$ of rainfall. According to the described protocol, during the first month, it corresponded to $87.5 \mathrm{~mm}$ of rainfall, then $50 \mathrm{~mm}$ of rainfall for the second and the third month. During three months of experiment an average rainfall of $62.5 \mathrm{~mm}$ was then applied. Considering that average rainfall $61.66 \mathrm{~mm} / \mathrm{month}$ is observed in Nice (French Riviera, France) this experimental protocol is coherent with the average rainfall in the area. Rainfall events were simulated during ES1 and ES2 by successive leaching/aeration of sediment using tap water. We used tap water to keep the same water that port authority considered during previous aeration/humidification procedures. Thus we could evaluate the benefit of mineral amendment, avoiding increased pollutant mobility provoked by artificial acid rainwater addition. Carbonate ions from the tap water used is ES1 and ES2 can contribute to limit the mobility of pollutants by complexation or co-precipitation processes. Leachates were collected in plastic containers placed under each box after $1 \mathrm{~h}$ of natural drainage through the materials. For all samples, after rainfall simulation, leachates were filtrated (through $0.45 \mu \mathrm{m}$ regenerated cellulose membranes Minisart RC15, Sartorius), collected in 3 different plastic tubes and acidified with $10 \mu \mathrm{L}$ of concentrated nitric acid. To evaluate the benefits of RM, we have chosen to focus on $\mathrm{As}, \mathrm{Cd}, \mathrm{Cr}, \mathrm{Cu}, \mathrm{Ni}$, and $\mathrm{Zn}$, which are among the elements pointed out by sediment quality guidelines, and also Mo since a previous work has shown that it was highly mobilized from sediment during leaching experiments (Mamindy-Pajany et al., 2013). Unlike cationic elements, the availability of Mo to higher plant species generally increases with increasing soil $\mathrm{pH}$ and can be toxic (McBride et al., 2000; Jiang et al., 2015). Therefore, European Council included this element in the list of regulatory level for inert waste. Analysis of $\mathrm{As}, \mathrm{Cd}, \mathrm{Cr}, \mathrm{Cu}, \mathrm{Mo}, \mathrm{Ni}$, and $\mathrm{Zn}$ was performed with ICP-OES (Perkin Elmer, Optima 7300DV) previously calibrated with mono-elementary certified standard solutions (SCP Sciences). The variability of leachates collection was considered to be equal to the standard deviation obtained through analysis of the set of 3 tubes collected after each leaching procedure. Electrical conductivity (EC) and $\mathrm{pH}$ were monitored in leachates obtained after each rainfall event simulation. Climatic conditions (precipitation and temperature) during ES1 and ES2 are given in Table 3.

\subsection{Leachate toxicity}

Microtox $^{\circledR}$ test was carried out with the Gram-negative marine bioluminescent bacteria Vibrio fischeri using the Microtox ${ }^{\circledR}$ Model500 Test System (ISO, 2007). This method allowed measurement of light outputs at a wavelength of $490 \mathrm{~nm}$ with readings after $30 \mathrm{~min}$ time exposure at $15 \pm 1{ }^{\circ} \mathrm{C}$ to samples serial dilutions in triplicate. The light loss as a consequence of bacteria exposure to samples was the endpoint. A negative control (dilution water) and reference toxicant were carried out to comply with quality assurance and quality control procedures. Light emission was recorded and the output data analyzed using MicrotoxOmni ${ }^{\circledR}$ software Version 1.18 (Libralato et al., 2010a). Toxicity with $V$. fischeri was measured for leachates obtained after the first day (day 1) and last day (day 89) of experiment. In addition, the toxicity of BX, BS and 
Table 3

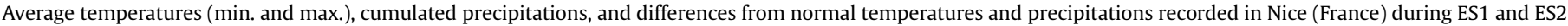
(source http://www.infoclimat.fr/).

\begin{tabular}{|c|c|c|c|c|c|c|c|}
\hline & Month & $\mathrm{T}_{\mathrm{av}-\min }\left({ }^{\circ} \mathrm{C}\right)$ & Diff. from norm. $\left({ }^{\circ} \mathrm{C}\right)$ & $\mathrm{T}_{\mathrm{av}-\max }\left({ }^{\circ} \mathrm{C}\right)$ & Diff. from norm. $\left({ }^{\circ} \mathrm{C}\right)$ & Cumul. ppav $(\mathrm{mm})$ & Diff. from norm. (\%) \\
\hline \multirow[t]{4}{*}{ ES1 (2013) } & March & 7.8 & +0.6 & 13.3 & -1.2 & 243 & +245 \\
\hline & April & 11.2 & +1.5 & 17.3 & +0.6 & 82.2 & +32 \\
\hline & May & 13.1 & +0.1 & 19.1 & -0.7 & 115.8 & +138 \\
\hline & June & 17 & +0.5 & 22.8 & -0.5 & 25.7 & -28 \\
\hline \multirow[t]{4}{*}{ ES2 (2014) } & April & 12.4 & +2.6 & 18.2 & +1.5 & 8 & -87 \\
\hline & May & 14.1 & +1 & 20.6 & +0.8 & 18.8 & -61 \\
\hline & June & 18.9 & +2.4 & 25.4 & +2.1 & 10.3 & -71 \\
\hline & July & 20 & +0.7 & 26 & -0.4 & 28.4 & +82 \\
\hline
\end{tabular}

GBX as a whole was evaluated. Toxicity was expressed both as percentage of effect (PE) and median effective concentration (EC50) if calculable. Microtox ${ }^{\circledR}$ EC50 values were obtained after linear regression between sample concentration and the fraction of light loss to light remaining (G) in a logarithmic scale with $95 \%$ confidence limit values. After the verification of homoscedasticity ( $F$ test, $\mathrm{p}<0.05$ ) and normality (Shapiro-Wilk test, $\mathrm{p}<0.05$ ) of data, the significance of differences between average values of different experimental treatments and controls was assessed by the analysis of variance (ANOVA, $\mathrm{p}<0.05$ ). When ANOVA revealed significant differences among treatments, post-hoc tests were carried out with Tukey's test $(\mathrm{p}<0.05)$. Leachates were verified for $\mathrm{pH}$ compliance with standard protocol requirement (ISO, 2007) within the range 6.0-8.5 and adjusted with drops of $\mathrm{HCl} 1 \mathrm{M}$ if necessary.

Physico-chemical and toxicity data were elaborated looking for the relationships between variables and the variation present in the dataset matrix via biplotting both the ordination component scores and the variable loading coefficients through Principal Component Analysis (PCA) based on the Pearson's correlation matrix; no data transformation was necessary. Statistical analyses were carried out using Microsoft ${ }^{\circledR}$ Excel 2013/XLSTAT@-Pro (Version 7.2, 2003, Addinsoft, Inc., Brooklyn, NY, USA).

\section{Results and discussion}

\subsection{Trends of $\mathrm{pH}$ and $E C$}

Trends of pH and EC during 3 months observation were presented in Fig. 1 and in Fig. 2 for $5 \%$ and $20 \%$ of amendment, respectively. Evolution of $\mathrm{pH}$ is comparable to control sediment (CS) when 5\% BX and 5\% BS were added (Fig. 1). pH values slightly increased during the experiment, starting at $\mathrm{pH}=8$ and ending up at $\mathrm{pH}>8.10$. When $5 \% \mathrm{GBX}$ was added, $\mathrm{pH}$ was systematically higher than for CS, $5 \% \mathrm{BX}$ and $5 \% \mathrm{BS}$ due to the partial dissolution of gypsum. Addition of $20 \%$ of BX and BS (i.e. alkaline materials) (Fig. 2) induced a global increase of the $\mathrm{pH}$ value compared to Fig. 1. This global increase in $\mathrm{pH}$ was amplified when GBX was added to sediment. Hence, the addition of mineral amendment has minor impact on $\mathrm{pH}$ as long as it is introduced at low rate. Amendment with gypsum provoked an increase in $\mathrm{pH}$ values whatever the amendment rate due to partial dissolution of gypsum. Sediment from this study has a natural buffer capacity due to its carbonate content. Since $\mathrm{pH}$ has a crucial impact on pollutant mobility, this parameter has to be considered in data interpretations.

Regarding EC, it decreased (from approx. $50 \mathrm{mS} / \mathrm{cm}$ to $15 \mathrm{mS}$ / $\mathrm{cm}$ ) irrespectively of the amendment rate during the first $10 \mathrm{~d}$, then kept a constant value (approx $15 \mathrm{mS} / \mathrm{cm}$ ) from day 10-40. From day $1-40$, the decrease and stabilization of EC is coherent with addition of tap water with low EC, resulting in the decrease of natural sediment salinity. Zhang et al. (2014) reported that high salinity can inhibit the growth and activity of sulfate reducing bacteria by
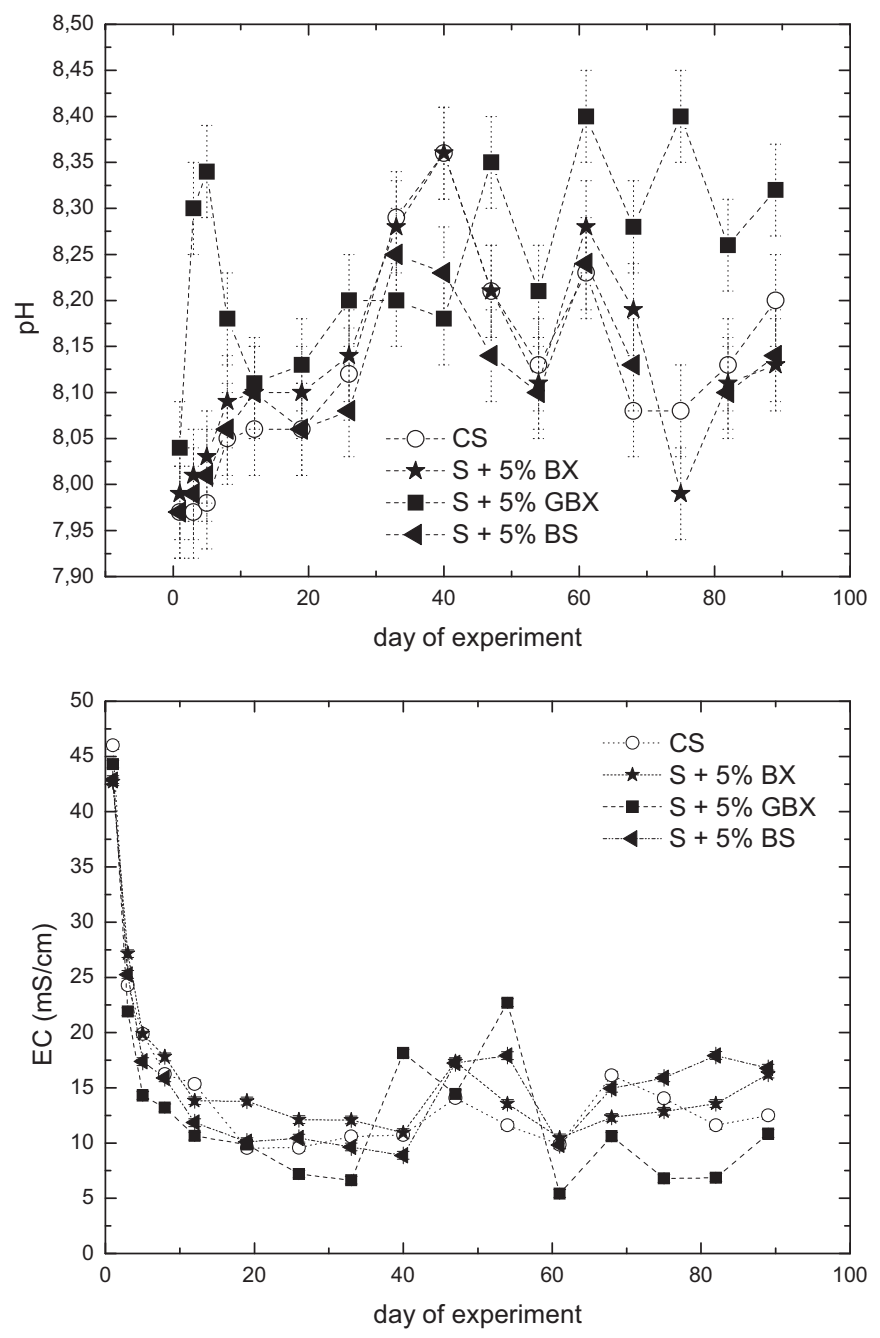

Fig. 1. Trends of $\mathrm{pH}$ and electrical conductivity (EC) for $5 \%$ amendment; $\mathrm{CS}=$ control sediment; $\mathrm{BX}=$ bauxaline ${ }^{\circledR} ; \mathrm{BS}=$ bauxsol $^{\mathrm{TM}} ; \mathrm{GBX}=$ bauxaline ${ }^{\circledR}$ with gypsum (standard deviation for EC: $\pm 0.35 \mathrm{mS} / \mathrm{cm}$; standard deviation for $\mathrm{pH}: \pm 0.05$ ).

increasing cell osmotic pressure and repressing metabolic enzymes, and thus affected the reduction of $\mathrm{SO}_{4}^{2-}$ and the decomposition of organic matter in sediment, resulting in increasing metals bioavailability. The decrease in salinity provoked by tap water addition to dredged sediment could decrease metals bioavailability; nevertheless the aerobic experimental conditions encountered during ES1 and ES2 are not favorable to reduction reactions (Zhang et al., 2014). After 40 d, EC varied significantly up to the end of experiments probably due to the partial dissolution of mineral phases of sediment or amendment. ES2 was conducted during a 

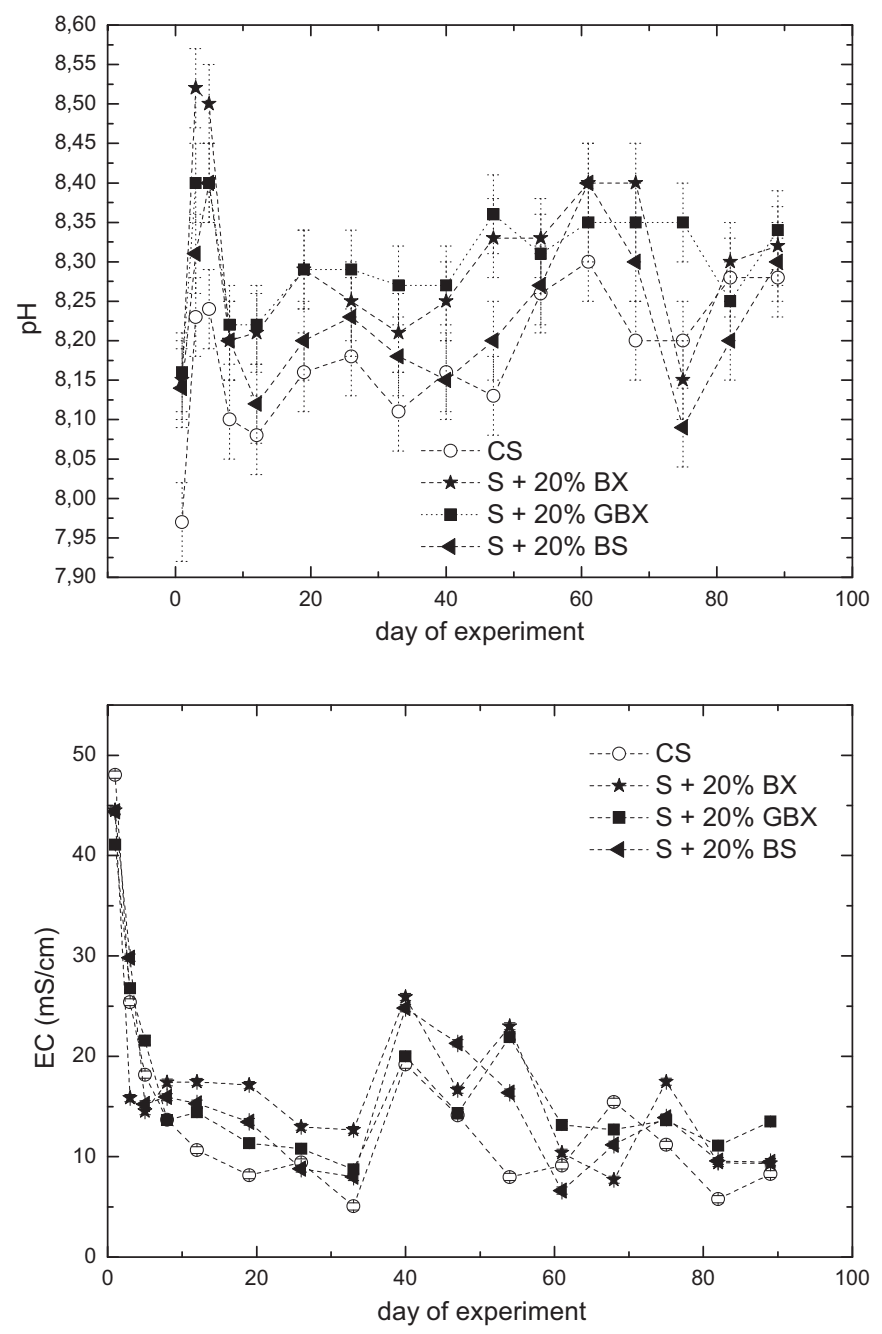

Fig. 2. Trends of $\mathrm{pH}$ and electrical conductivity (EC) for $20 \%$ amendment; $\mathrm{CS}=$ control sediment; $\mathrm{BX}=$ bauxaline $^{\circledR} ; \mathrm{BS}=$ bauxsol $^{\mathrm{TM}} ; \mathrm{GBX}=$ bauxaline $^{\circledR}$ with gypsum (standard deviation for EC: $\pm 0.35 \mathrm{mS} / \mathrm{cm}$; standard deviation for $\mathrm{pH}: \pm 0.05$ ).

period that was hotter and dryer than ES1 (Table 3). Cumulative precipitations were abnormally lower than the normal precipitations observed from April to June and average temperatures were above the temperatures usually recorded during the same period. The unusually hot and dry climatic conditions during ES2 may probably have an impact on the experimental setup, explaining the high variation of EC from day 40 observed for $20 \%$ amendment (Fig. 2) and 5\% GBX (Fig. 1) in addition with mineral dissolution. Inversely, ES1 was carried out in temperature conditions under normality compared to the temperature usually recorded, but humidity was higher compared to the normal conditions (up to $+245 \%$ ).

\subsection{Trends of elements concentrations}

The concentration of $\mathrm{As}, \mathrm{Cd}, \mathrm{Cr}, \mathrm{Cu}, \mathrm{Ni}, \mathrm{Mo}$, and $\mathrm{Zn}$ measured in leachates collected after day 1 and day 89 during ES1 and ES2 are displayed in Fig. 3 and Fig. 4,respectively. Arsenic behavior during ES2 and ES1 did not significantly differ from CS meaning that bauxite residues are not convenient to stabilize As since adsorption conditions are not favored (As adsorption occurs at acidic $\mathrm{pH}$ values). After dredging, aerobic conditions could have induced partial or total oxidation of iron oxides and organic matter from the sediment matrix leading to an increased mobility of As (Dang et al., 2014). The addition of gypsum did not improve As stabilization since the increase in competing anions due to gypsum dissolution could limit As adsorption on bauxite additive surface. As mobility has already been reported both at basic and acidic $\mathrm{pH}$ and this very specific behavior was attributed to the acid-base properties (amphoteric nature) of aqueous As (Saussaye et al., 2016; Tabelin et al., 2014).

When 5\% amendment was applied, the amount of $\mathrm{Cr}$ in all leachates was $<15 \mu \mathrm{g} / \mathrm{kg}$. On the other hand when $20 \%$ amendment was considered, $\mathrm{Cr}$ in the leachates reached up to $30 \mu \mathrm{g} / \mathrm{kg}$. Concentration of $\mathrm{Cr}$ found in BX, BS and GBX (Table 2) confirmed that $\mathrm{Cr}$ is supplied to sediment by the amendment. Nevertheless it can be noticed that the leached amount of $\mathrm{Cr}$ when $20 \% \mathrm{GBX}$ was used is lower than when 20\% BX and 20\% BS amendments were considered. Despite its direct presence in amendments, $\mathrm{Cr}$ is rapidly leached during the first days of experiment and a significant decrease in its concentration was observed after day 89. Saussaye et al. (2016) noticed that in alkaline $\mathrm{pH}$ conditions, $\mathrm{Cr}$ mobility was limited in a larger extent. When $20 \% \mathrm{GBX}$ was added, the $\mathrm{pH}$ of the media was slightly higher than for the other amendments. The limited mobility of $\mathrm{Cr}$ observed in these conditions could be directly linked to the $\mathrm{pH}$ conditions due to precipitation of $\mathrm{Cr}$ hydroxide in circumneutral pH (Burke et al., 2012), by formation of inner sphere surface complex $\left(\mathrm{CrSO}_{4}^{+}\right)$following gypsum dissolution or by formation of organic-Cr(III) surface complex (Aström and Corin, 2000).

Stabilization of Mo in sediment was significantly more effective when high amounts of amendment were used. When 20\% BS and $20 \%$ BX were added to sediment, the amount of leached Mo was significantly reduced compared to CS, 5\% BS and 5\% BX. GBX seemed to effectively stabilize Mo even at low amendment rates (5\%). But a similar trend was observed in CS without any additive in ES2, but not in ES1. This event could be related to ES2 climatic conditions (up to $+2.6^{\circ} \mathrm{C}$ and $-87 \%$ precipitations compared to the normal conditions). Indeed, Fox and Doner (2002) evidenced that Mo turns into water-soluble forms after air-drying.

In both ES1 and ES2, Cd was easily leached from sediment after day 1. Previous works showed that $\mathrm{Cd}$ was linked to the redox sensitive fraction of sediments (Baraud and Leleyter, 2012; Hamdoun et al., 2015). Regular aeration by manual homogenization of sediment during experiments (ES1 and ES2) favored oxidation reactions and, probably, an increased mobility of $\mathrm{Cd}$. The addition of BX, BS, and GBX to sediment decreased the amount of leached Cd starting from day 1 . The amount of leached Cd was lower during ES2 compared to ES1 suggesting that high amendment rates are more performing. No significant changes in leached Cd were observed when GBX was used compared to BX and BS, meaning that $\mathrm{Cd}$ preferentially adsorbs at the surface of bauxite residues.

In CS and in 5\% GBX, the concentrations of $\mathrm{Zn}(303 \mu \mathrm{g} / \mathrm{kg}$ and $231 \mu \mathrm{g} / \mathrm{kg})$ and $\mathrm{Cu}(244 \mu \mathrm{g} / \mathrm{kg}$ and $152 \mu \mathrm{g} / \mathrm{kg})$ in leachates were high after day 1 (Fig. 4). After day 89, $\mathrm{Zn}$ and $\mathrm{Cu}$ amounts in leachates were significantly lower than after day 1 (inferior to $20 \mu \mathrm{g} / \mathrm{kg}$ and inferior to $70 \mu \mathrm{g} / \mathrm{kg}$, respectively) meaning that a rate of amendment equal to $5 \%$ can be efficient for their stabilization in sediment. According to literature data, $\mathrm{Zn}$ and $\mathrm{Cu}$ are mainly present in the acid-soluble, redox sensitive fraction, and the organic/sulphide fraction of sediments, respectively (Hamdoun et al., 2015; Emili et al., 2016). As noticed for Cd, manual aeration of sediment during ES1 and ES2 could enhance mobilization of $\mathrm{Cu}$ and $\mathrm{Zn}$ due to oxidation of mineral phases. Addition of BX, BS and GBX at high and low rates significantly decreased the leached amounts of $\mathrm{Zn}$ and $\mathrm{Cu}$ after day 1 . This means that $\mathrm{Zn}$ and $\mathrm{Cu}$ are highly reactive towards bauxite residues, and adsorption process is favored in the 

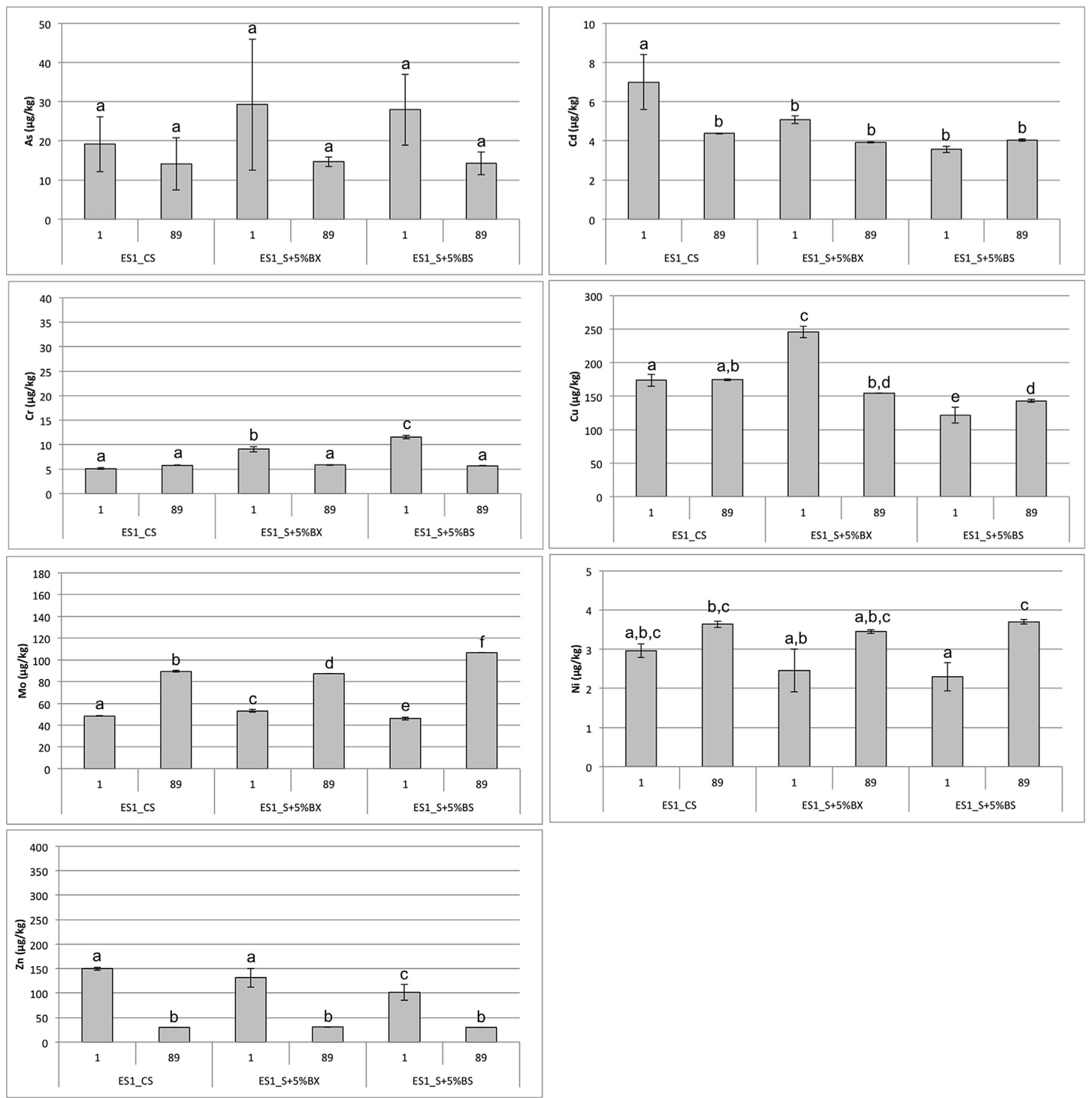

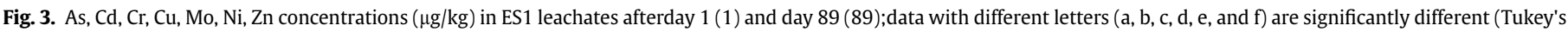
test); $\mathrm{CS}=$ control sediment; $\mathrm{BX}=$ bauxaline $^{\mathbb{R}} ; \mathrm{BS}=$ bauxsol $^{\mathrm{TM}}$

experimental conditions even at low amendment rate.

Ni concentrations in leachates of CS, 5\% BX and 5\% BS were < $3 \mu \mathrm{g} / \mathrm{kg}$ after day 1 . After day 89 , leached $\mathrm{Ni}$ was slightly higher $(<4 \mu \mathrm{g} / \mathrm{kg})$ than day 1 . Ni has a very limited mobility as shown by the concentrations measured in leachates from ES1 and ES2. Ni is generally linked to the alumino-silicate fraction of sediments (Algan et al., 2004), which is not soluble or oxidizable at the $\mathrm{pH}$ conditions encountered during ES1 and ES2. Addition of 20\% amendment increased Ni stabilization compared with $5 \%$ amendment since $\mathrm{Ni}$ concentration was below the detection limit of
ICP-OES. For this reason, no results about Ni are provided for ES2.

Leaching rates during the whole experiment were calculated considering the cumulated leached concentration of each element and accounting for the total concentration of each element measured in the whole sediment sample as previously described (Taneez et al., 2015; Taneez et al., 2016) (Table 4). In the case of As and Mo, leaching rates were similar to the ones obtained in CS, meaning that stabilization was not improved by the addition of $5 \%$ amendment. When 20\% amendment was used, leaching rates remained $<1 \%$ for all elements except for Mo compared to their 

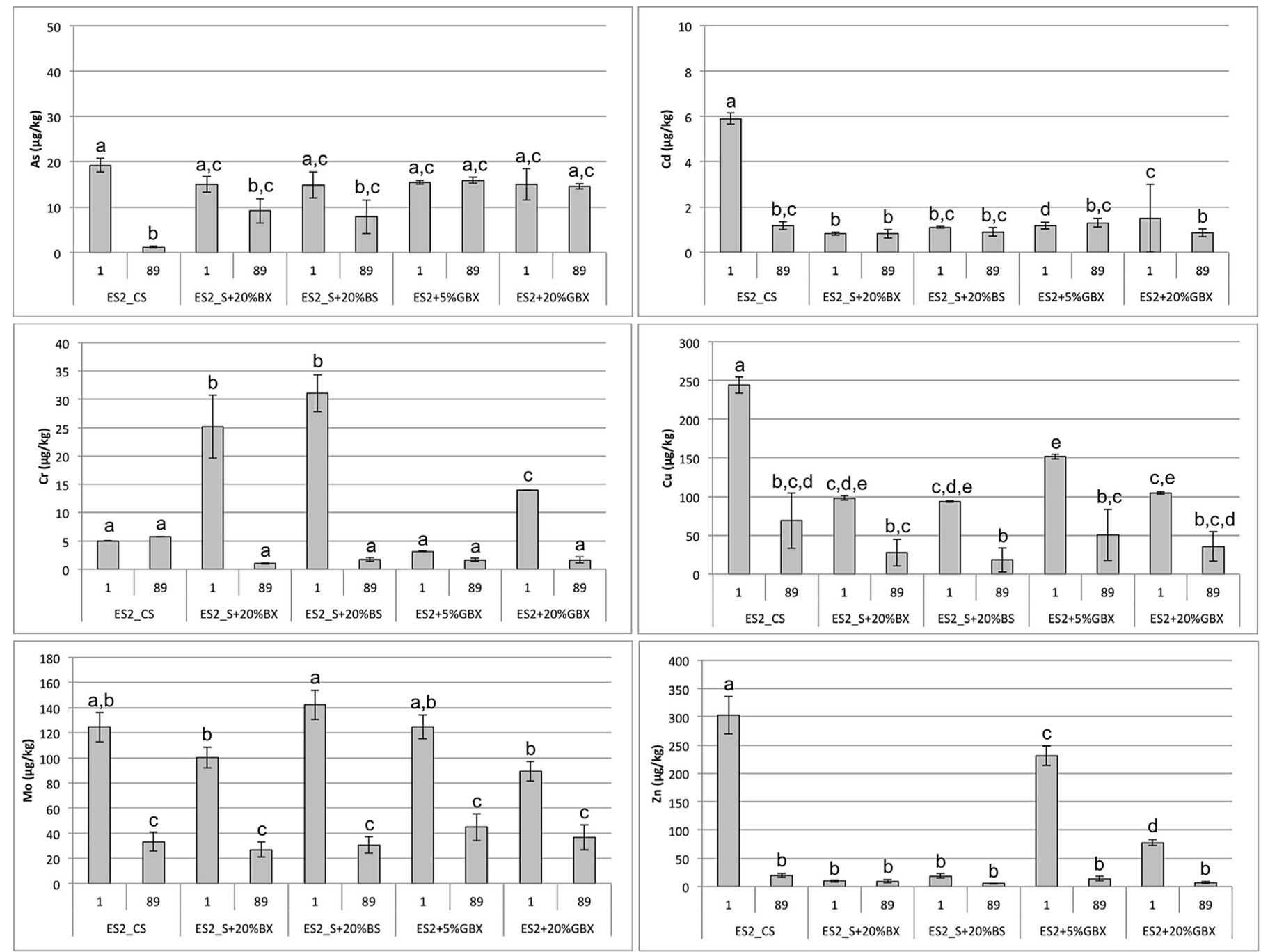

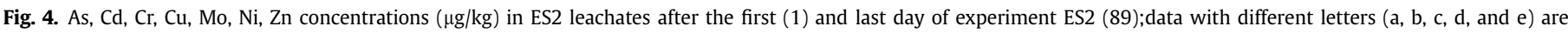
significantly different (Tukey's test).

total concentration in sediment matrix, meaning that less than $1 \%$ of total contaminants are available, while $99 \%$ are stored in the sediment (Salomons, 1998).

It can be concluded that addition of $5 \%$ BX or $5 \%$ BS did not significantly improve stabilization of trace elements and, sometimes, sediment heterogeneity can mask the performance assessment of mineral amendments at low rate. Nevertheless, for Mo, $\mathrm{Zn}$ and $\mathrm{Cu}$, satisfactory stabilization results were obtained as soon as $5 \%$ GBX was applied. Amendment with $20 \%$ of additive is more performing to stabilize trace elements in aerated/humidified sediment especially for $\mathrm{Cd}, \mathrm{Cu}$, Mo and $\mathrm{Zn}$. ES2 was conducted during a hot and dry period (May-July 2014), whereas ES1 was carried out from March to June 2013, which was an unusually humid and cold period. Climatic conditions during ES2 could explain the increased mobility of Mo during the dryer period as previously reported (Fox and Doner, 2002). This variation in climatic conditions makes difficult the direct comparison between ES1 and ES2. The governing factors for the metal retention and leaching are chemical conditions such as surface site saturation, redox conditions, biological processes, $\mathrm{pH}$, competing ions, and associated kinetics. Kumar et al. (2013) observed that metal mobility and bioavailability increased as a function of time during sediment leaching. This suggested a

Table 4

Total leaching rates (\%) obtained after ES1 and ES2.

\begin{tabular}{|c|c|c|c|c|c|c|c|c|}
\hline $\begin{array}{l}\text { Elements } \\
\text { Leaching rate (\%) }\end{array}$ & $\begin{array}{l}\text { Control sediment } \\
\text { ES1 }\end{array}$ & $\begin{array}{l}\text { Control sediment } \\
\text { ES2 }\end{array}$ & $\mathrm{S}+5 \% \mathrm{BX}$ & $S+5 \%$ BS & $\mathrm{S}+5 \% \mathrm{GBX}$ & $S+20 \% B X$ & $\mathrm{~S}+20 \% \mathrm{BS}$ & $\mathrm{S}+20 \% \mathrm{GBX}$ \\
\hline As & 0.20 & $<0.10$ & 0.21 & 0.19 & $<0.10$ & $<0.10$ & $<0.10$ & $<0.10$ \\
\hline $\mathrm{Cd}$ & 0.60 & 0.63 & 0.33 & 0.34 & 0.47 & 0.21 & 0.23 & 0.28 \\
\hline $\mathrm{Cu}$ & 0.15 & 0.12 & 0.12 & $<0.10$ & $<0.10$ & $<0.10$ & $<0.10$ & $<0.10$ \\
\hline Mo & 9.50 & 12.9 & 8.83 & 10.2 & 12.6 & 12.3 & 14.4 & 11.4 \\
\hline $\mathrm{Ni}$ & 0.10 & - & $<0.10$ & $<0.10$ & - & - & - & - \\
\hline $\mathrm{Zn}$ & $<0.10$ & $<0.10$ & $<0.10$ & $<0.10$ & $<0.10$ & $<0.10$ & $<0.10$ & $<0.10$ \\
\hline $\mathrm{Cr}$ & 0.10 & 0.15 & $<0.10$ & $<0.10$ & $<0.10$ & $<0.10$ & $<0.10$ & $<0.10$ \\
\hline
\end{tabular}



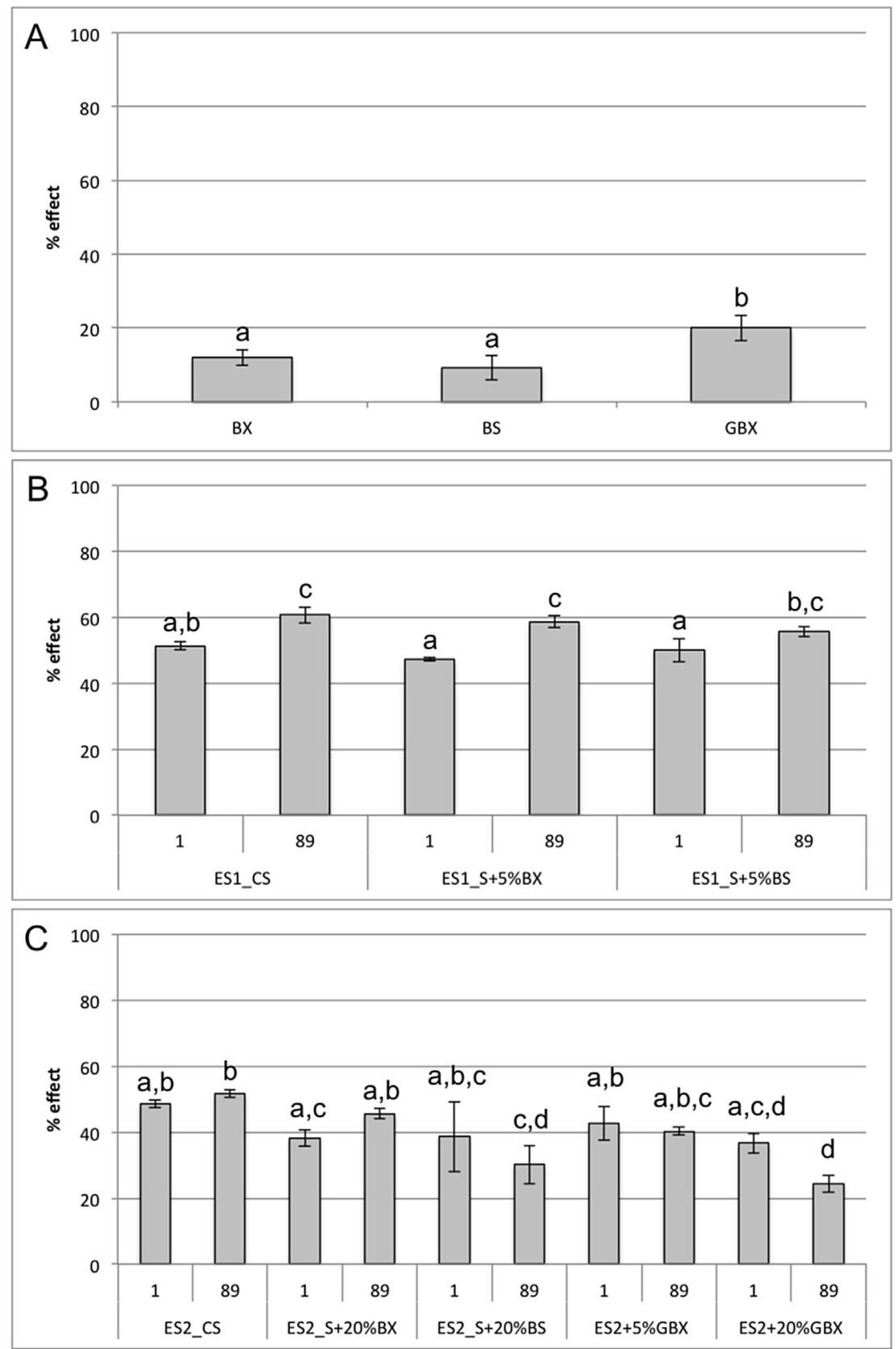

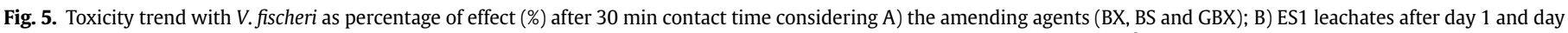

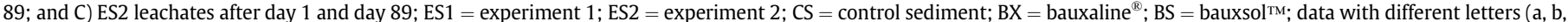
c, and d) are significantly different (Tukey's test).

kinetically controlled transfer of trace elements towards exchangeable fraction. Sediment dredging and aerobic disposal activities are expected to drastically disrupt the initial equilibrium since trace elements partitioning in anoxic sediments is dominated by the formation of sulfide phases. Oxidative conditions encountered during disposal of dredged sediments determined the release of trace elements, increased acidity, and iron and sulfate release (Chatain et al., 2013). To prevent mobilization of contaminants from dredged sediments during land management, treatments such as cement addition (Chatain et al., 2013) and mineral amendment have been investigated (Mamindy-Pajany et al., 2013). When cement addition was considered, a very limited release of $\mathrm{Pb}, \mathrm{Cu}$, and $\mathrm{Zn}$ was observed. Cement stabilization induced high buffering capacity controlled by the dissolution of cementitious phases for
pH values between 10 and 12 promoting metal fixation. However, under specific leaching conditions, a risk of contaminant mobilization exists, specifically for anionic pollutants (Chatain et al., 2013). When commercial mineral amendments were used, hematite was found to be the most effective for trace elements stabilization compared to goethite and $\mathrm{Fe}(0)$, except for As which was continuously leached whatever the amendment (Mamindy-Pajany et al., 2013). The use of industrial by-products such as bauxite residues offers satisfactory results for the stabilization of cationic pollutants and Mo, when high amendment rates are applied. Nevertheless, some limitations can be pointed out about their use. Indeed, the regulatory levels $\mathrm{N} 1$ and $\mathrm{N} 2$ that were defined for dredged sediment do not include elements such as $\mathrm{V}$, which is present in high concentrations in bauxite residues (Table 2). 
Vanadium is a key contaminant of concern identified in RM (Burke et al., 2012). At basic pH, vanadate dominates the aqueous speciation and, when $\mathrm{pH}$ is lowered, vanadate adsorption is expected to increase onto the mineral phases (either the neoformed ones or the RM intrinsic ones). Nevertheless, effective adsorption of vanadate has not been observed at circumneutral $\mathrm{pH}$, especially when surface loadings are elevated, making neutralization inefficient in removing aqueous V (Burke et al., 2012). Hence, at neutral pH, V represents a potential secondary pollution risk since neutralized RM could be a source of soluble V. On this basis, it is not sufficient to limit studies to the elements that have been focused in compliance with regulatory standards. Specific regulations relative to the use of industrial by-products for chemical stabilization purposes should be elaborated looking at the End-of-Waste Directive (Council Regulation (EU) n. 333/2011).

\subsection{Toxicity with Vibrio fischeri}

Toxicity effects of leachates after ES1 and ES2 were summarized in Fig. 5 including the toxicity of BX, BS and GBX. Results from negative and positive controls were in line with the standard protocol. BX and BS toxicity was not significantly different (Fig. 5A) and equal to $12 \% \pm 2 \%$ and $11 \% \pm 3 \%$, respectively. Data indicated slight acute toxicity effects (Libralato et al., 2010b), but proxy to $10 \%$ effect that is generally considered a non-toxicity threshold in most toxicity tests (Lofrano et al., 2016b). GBX presented slight acute toxicity effects $(20 \% \pm 3 \%)$ probably related to the dissolution of gypsum contained in GBX.

EC50 values were not calculable either for ES1 or for ES2 for all leachates. Thus only the percentage of effect is available.

During ES1, the toxicity of leachates after day 1 was $51 \% \pm 1 \%$, $47 \% \pm 1 \%$, and $50 \% \pm 3 \%$ for CS, $5 \%$ BX and $5 \%$ BS, respectively. The toxicity of leachates after day 89 was $61 \% \pm 3 \%, 59 \% \pm 2 \%$, and $56 \% \pm 2 \%$ for CS, BX and BS, respectively. According to Fig. $5 \mathrm{~B}$, the toxicity significantly increased after the treatment period (day 1-89) both in CS and treatments (BX and BS) suggesting that 5\% BX and $5 \%$ BS did not provide a significant contribution to treated sediment stabilization and thus toxicity reduction/removal, confirming physico-chemical data.

During ES2, the toxicity of leachates after day 1 was $49 \% \pm 1 \%$, $38 \% \pm 3 \%, 39 \% \pm 11 \%, 37 \% \pm 3 \%$, and $43 \% \pm 5 \%$ for CS, $20 \%$ BX, $20 \%$ BS, $20 \%$ GBX, and 5\% GBX, respectively (Fig. 5C). Toxicity of leachates after day 1 showed to be not significantly different between treatments. The toxicity of leachates after day 89 was $52 \% \pm 1 \%$, $46 \% \pm 2 \%, 30 \% \pm 6 \%, 24 \% \pm 3 \%$, and $40 \% \pm 1 \%$ for CS, $20 \%$ BX, $20 \%$ BS, $20 \%$ GBX, and 5\% GBX, respectively. Toxicity showed to significantly decrease (65\%) only after the addition of $20 \%$ GBX reaching effects not significantly different from GBX $(20 \% \pm 3 \%)$. All other treatments did not significantly remove toxicity.

In general, sediment leached after ES2 showed lower amounts of As, $\mathrm{Cd}, \mathrm{Cu}$, and approximately the same amounts of Mo of ES1 leachates. Conversely, the amount of $\mathrm{Cr}$ and $\mathrm{Zn}$ leached during ES2 was slightly greater compared to ES1. About toxicity, ES2 leachates were less toxic than ES1 correlating with the general lower amount of leached elements. The higher amount of $\mathrm{Cr}$ leached during ES2 when $20 \%$ BS, 20\% BX and 20\% GBX were administered, had no impact on leachate toxicity.

Results from principal component analysis (Fig. 6) showed that the first two principal components accounted for $47.52 \%$ and $20.38 \%$ of the variation, respectively. The biplot regarding components loadings suggested that F1 scores are influenced by As (11\%), $\mathrm{Ni}(11 \%)$, V. fischeri toxicity (13\%), Cd (24\%), Cu (24\%), and Zn (13\%), while $\mathrm{F} 2$ by $\mathrm{Cr}$ (37\%) and Mo (34\%). Looking at the ordination plot of component scores in the F1 and F2 biplot, samples could be clustered in four main groups (clockwise in Fig. 6): i) samples relatively slightly influenced by the considered variables (G1); ii) samples influenced by F2 variables (G2); iii) samples averagely influenced by F1 and F2 variables (G3); and iv) samples influenced by F1 variables (G4). Leachates clustered in G4 appeared the most toxic and contaminated, and conversely for G1 specimen. According to Pearson's correlation coefficients, toxicity was correlated to $\mathrm{Cu}$ (0.573), Cd (0.624) and $\mathrm{Ni}(0.755)$. Cu was also correlated to As (0.533), Cd (0.723), Ni (0.641), and $\mathrm{Zn}(0.879)$. Cr and Mo were significantly correlated each other (0.538).

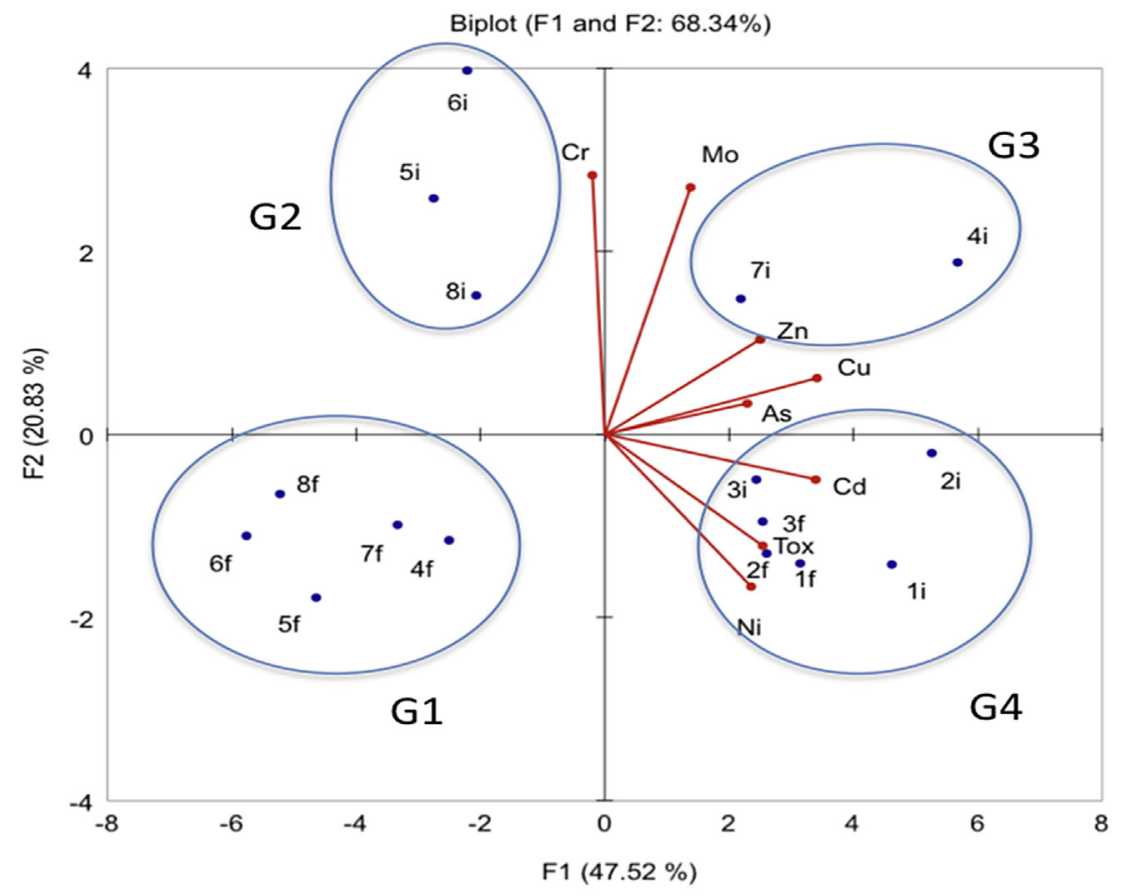

Fig. 6. Principal component analysis (PCA) of chemical and toxicity data obtained for ES1 and ES2; Tox = V. fischeri 30 min toxicity; for label conversion please see S2. 


\section{Conclusion}

Stabilization of trace metals was investigated using bauxite extraction by-products (red mud) as mineral amendment (bauxaline ${ }^{\circledR}$, bauxsol ${ }^{\mathrm{TM}}$ and gypsum neutralized bauxaline ${ }^{\circledR}$ ) to pretreated dredged marine sediment. As, $\mathrm{Cd}, \mathrm{Cu}, \mathrm{Ni}$, and $\mathrm{Zn}$ were selected for this research study since their monitoring is compulsory according to sediment quality guidelines; Mo was included too since its presence was recorded in sediment. Application of bauxaline $^{\circledR}$, bauxsol ${ }^{\mathrm{TM}}$ and gypsum neutralized bauxaline ${ }^{\circledR}$ at any rate $(5 \%$ or $20 \%$ ) was found to be not efficient for As stabilization. Application of $5 \%$ bauxaline ${ }^{\circledR}$ or bauxsol ${ }^{\mathrm{TM}}$ was not adequate to significantly reduce $\mathrm{Cd}, \mathrm{Mo}, \mathrm{Ni}, \mathrm{Zn}$ and $\mathrm{Cu}$ in leachates, while application of $5 \%$ gypsum neutralized bauxaline ${ }^{\circledR}$ slightly improved stabilization of $\mathrm{Zn}, \mathrm{Cu}$ and Mo. In the present study scenarios, the higher amendment rate (20\%) (bauxaline ${ }^{\circledR}$, bauxsol ${ }^{\mathrm{TM}}$, and gypsum neutralized bauxaline $\left.{ }^{\circledR}\right)$ was more efficient in trace metal stabilization compared to 5\%, except for As. During the first days of experiments, $\mathrm{Cr}$ was leached when bauxite residues were added to sediment. Leachates collected from the sample containing amendment of gypsum neutralized bauxaline ${ }^{\circledR}(20 \%)$ were less toxic compared to the control, and approximately as toxic as the control when $5 \%$ of amendment was used. A decrease in toxicity was also observed at the end of the experiment when $20 \%$ of amendment rate was applied compared to the first day of experiment. Considering toxicity and chemical results, gypsum neutralized bauxaline ${ }^{\circledR}$ should be preferred for stabilization purposes. From EC and metal leaching measurements, on land storage of dredged marine sediment investigated should not exceed 40 days especially when sediment is exposed to regular and intense rainfall. Indeed, mineral dissolution as a consequence of regular and intense rainfalls, $\mathrm{pH}$ variation, and aerobic conditions should increase trace elements mobility. For stabilization purposes, the use of industrial by-products mixed with contaminated sediment should be submitted to specific regulations since pollutants such as $\mathrm{Cr}$ and $\mathrm{V}$ (among others) stemming from the mineral amendment can be importantly leached. In the present study, despite that experiments were conducted outside and under cover, very dry and hot periods influenced metal mobility (especially Mo), but this point deserves deeper investigations. Hence, climatic conditions should not be neglected, specifically when sediments have to be managed on land. Additional pilot experiments such as the one described in this study should be carried out considering other treatments of bauxite extraction by-products such as acid, thermal or combined chemical/thermal treatments to get an exhaustive comparative study.

\section{Appendix A. Supplementary data}

Supplementary data related to this article can be found at http:/ dx.doi.org/10.1016/j.envpol.2016.09.072.

\section{References}

Algan, O., Balkis, N., Cagatay, M.N., Sari, E., 2004. The sources of metal contents in the shelf sediments from the Marmara Sea, Turkey. Environ. Geol. 46, 932-950.

Alvarez, J., Rosal, R., Sastre, H., Diez, F.V., 1995. Characterization and deactivation of sulfided red mud used as hydrogenation catalyst. Appl. Catal. A Gen. 128 259-273.

Alzieu, C., 1999. Dragages et environnement marin: état des connaissances= Dredging and Marine Environment: State of the Art.

Alzieu, C., 2005. Dredging and Marine Environment. Editions Quae.

Alzieu, C., Quiniou, F., 2001. Software to assess risks related to dumping of dredged sediments from maritime harbours. Geodrisk. CD-ROM Geodrisk.

Andral, B., Stanisiere, J.Y., Sauzade, D., Damier, E., Thebault, H., Galgani, F. Boissery, P., 2004. Monitoring chemical contamination levels in the Mediterranean based on the use of mussel caging. Mar. Pollut. Bull. 49, 704-712.

Arizzi Novelli, A., Losso, C., Libralato, G., Tagliapietra, D., Pantani, C., Ghirardini, A.V., 2006. Is the 1: 4 elutriation ratio reliable? Ecotoxicological comparison of fou different sediment: water proportions. Ecotoxicol. Environ. Saf. 65, 306-313.

Aström, M. Corin, N., 2000. Abundance, sources and speciation of trace elements in humus-rich streams affected by acid sulphate soils. Aquat. Geochem. 6, 367-383.

Baraud, F., Leleyter, L., 2012. Prediction of phytoavailability of trace metals to plants: comparison between chemical extractions and soil-grown radish. Comptes Rendus Geosci. 344, 385-395.

Burke, I.T., Mayes, W.M., Peacock, C.L., Brown, A.P., Jarvis, A.P., Gruiz, K., 2012. Speciation of arsenic, chromium, and vanadium in red mud samples from the Ajka Spill Site, Hungary. Environ. Sci. Technol. 46, 3085-3092.

Burke, I.T., Peacock, C.L., Lockwood, C.L., Stewart, D.I., Mortimer, R.J.G., Ward, M.B., Renforth, P., Gruiz, K., Mayes, W.M., 2013. Behavior of aluminum, arsenic, and vanadium during the neutralization of red mud leachate by $\mathrm{HCl}$, gypsum, or seawater. Environ. Sci. Technol. 47, 6527-6535.

Chatain, V., Benzaazoua, M., Loustau Cazalet, M., Bouzahzah, H., Delolme, C., Gautier, M., Blanc, D., de Brauer, C., 2013. Mineralogical study and leaching behavior of a stabilized harbor sediment with hydraulic binder. Environ. Sci. Pollut. Res. 20, 51-59.

Dang, D.H., Tessier, E., Lenoble, V., Durrieu, G., Omanovic, D., Mullot, J.-U., Pfeifer, H.R. Mounier, S., Garnier, C., 2014. Key parameters controlling arsenic dynamics in coastal sediments: an analytical and modeling approach. Mar. Chem. 161, 34-46.

Doherty, F.G., 2001. A review of the Microtox ${ }^{\circledR}$ toxicity test system for assessing the toxicity of sediments and soils. Water Qual. Res. J. Can. 36, 475-518.

Duclay, E., Syndique, H., David, O., 2010. Groupe de travail n¹1-Sédiments de dragage, Le grenelle de la Mer. Direction de l'eau et de la biodiversité, Direction générale de la prévention des risques. République Française, France.

Duncan, R.N., 1973. 1972 convention on the prevention of marine pollution by dumping of wastes at Sea. J. Marit. Law \& Commer. 5, 299.

Eggleton, J., Thomas, K.V., 2004. A review of factors affecting the release and bioavailability of contaminants during sediment disturbance events. Environ. Int. 30, 973-980.

Emili, A., Acquavita, A., Covelli, S., Spada, L., Di Leo, A., Giandomenico, S., Cardellicchio, N., 2016. Mobility of heavy metals from polluted sediments of a semi-enclosed basin: in situ benthic chamber experiments in Taranto's Mar Piccolo (Ionian Sea, Southern Italy). Environ. Sci. Pollut. Res. 23, 12582-12595.

Evans, K., 2016. The history, challenges, and new developments in the management and use of bauxite residue. J. Sustain. Metallurgy 1-16.

Förstner, U., 2006. Contaminated Sediments: Lectures on Environmental Aspects of Particle-associated Chemicals in Aquatic Systems, vol. 21. Springer.

Fox, P.M., Doner, H.E., 2002. Trace element retention and release on minerals and soil in a constructed wetland. J. Environ. Qual. 31, 331-338.

Genç, H., Tjell, J.C., McConchie, D., Schuiling, O., 2003. Adsorption of arsenate from water using neutralized red mud. J. Coll. Interface Sci. 264, 327-334.

Gonzalez-Merchan, C., Perrodin, Y., Sébastian, C., Bazin, C., Winiarski, T., Barraud, S., 2014. Ecotoxicological characterisation of sediments from stormwater retention basins. Water Sci. Technol. 69.

Hamdoun, H., Leleyter, L., Van-Veen, E., Coggan, J., Basset, B., Lemoine, M., Baraud, F. 2015. Comparison of three procedures (single, sequential and kinetic extractions) for mobility assessment of $\mathrm{Cu}, \mathrm{Pb}$ and $\mathrm{Zn}$ in harbour sediments. Comptes Rendus Geosci. 347, 94-102.

ISO, 2007. 11348-3: Water Quality: Determination of the Inhibitory Effect of Water Samples on the Light Emission of Vibrio fischeri (Luminiscent Bacteria Test). International Organization for Standardization, London, UK.

Jiang, W., Yang, Z., Yu, T., Hou, Q., Zhong, C., Zheng, G., Yang, Z., Li, J., 2015. Evaluation of the potential effects of soil properties on molybdenum availability in soil and its risk estimation in paddy rice. J. Soils Sedim. 15, 1520-1530.

Kirwan, L.J., Hartshorn, A., McMonagle, J.B., Fleming, L., Funnell, D., 2013. Chemistry of bauxite residue neutralisation and aspects to implementation. Int. J. Miner. Process. 119, 40-50.

Komarek, M., Vanek, A., Ettler, V., 2013. Chemical stabilization of metals and arsenic in contaminated soils using oxides - a review. Environ. Pollut. 172, 9-22.

Kumar, M., Furumai, H., Kurisu, F., Kasuga, I., 2013. Potential mobility of heavy metals through coupled application of sequential extraction and isotopic exchange: comparison of leaching tests applied to soil and soakaway sediment. Chemosphere 90, 796-804.

Kumpiene, J., Lagerkvist, A., Maurice, C., 2008. Stabilization of As, Cr, Cu, Pb and $\mathrm{Zn}$ in soil using amendments-a review. Waste Manag. 28, 215-225.

Libralato, G., Annamaria, V.G., Francesco, A., 2010b. How toxic is toxic? A proposal for wastewater toxicity hazard assessment. Ecotoxicol. Environ. Saf. 73, 1602-1611.

Libralato, G., Ghirardini, A.V., Avezzù, F., 2010a. Toxicity removal efficiency of decentralised sequencing batch reactor and ultra-filtration membrane bioreactors. water Res. $44,4437-4450$.

Libralato, G., Losso, C., Novelli, A.A., Citron, M., Della Sala, S., Zanotto, E., Cepak, F., Ghirardini, A.V., 2008. Ecotoxicological evaluation of industrial port of Venice (Italy) sediment samples after a decontamination treatment. Environ. Pollut. 156, 644-650.

Llano, J.J., Rosal, R., Sastre, H., Diez, F.V., 1994. Catalytic hydrogenation of anthracene oil with red mud. Fuel 73, 688-694.

Lofrano, G., Libralato, G., Alfieri, A., Carotenuto, M., 2016a. Metals and tributyltin sediment contamination along the Southeastern Tyrrhenian Sea coast. Chemosphere 144, 399-407.

Lofrano, G., Libralato, G., Adinolfi, R., Siciliano, A., Iannece, P., Guida, M., Giugni, M., Ghirardini, A.V., Carotenuto, M., 2016b. Photocatalytic degradation of the 
antibiotic chloramphenicol and effluent toxicity effects. Ecotoxicol. Environ. Saf. $123,65-71$.

Mamindy-Pajany, Y., 2010. Traitement de sédiments portuaires méditerranéens contaminés en arsenic et en métaux. géochimie et écotoxicologie, Nice.

Mamindy-Pajany, Y., Geret, F., Roméo, M., Hurel, C., Marmier, N., 2012. Ex situ remediation of contaminated sediments using mineral additives: assessment of pollutant bioavailability with the Microtox solid phase test. Chemosphere 86, 1112-1116.

Mamindy-Pajany, Y., Hurel, C., Geret, F., Roméo, M., Marmier, N., 2013. Comparison of mineral-based amendments for ex-situ stabilization of trace elements (As, $\mathrm{Cd}, \mathrm{Cu}, \mathrm{Mo}, \mathrm{Ni}, \mathrm{Zn})$ in marine dredged sediments: a pilot-scale experiment. J. Hazard. Mater. 252, 213-219.

Mamindy Pajany, Y., Hurel, C., Marmier, N., Roméo, M., 2010. Tests de lixiviation et de stabilisation d'un sédiment portuaire contaminé à l'arsenic. Eur. J. Environ. Civ. Eng. 14, 233-251.

McBride, M.B., Richards, B.K., Steenhuis, T., Spiers, G., 2000. Molybdenum uptake by forage crops grown on sewage sludge-amended soils in the field and greenhouse. J. Environ. Qual. 29, 848-854.

Nadaroglu, H., Kalkan, E., Demir, N., 2010. Removal of copper from aqueous solution using red mud. Desalination 251, 90-95.

Onorati, F., Mecozzi, M., 2004. Effects of two diluents in the Microtox $\left.{ }^{(}\right)$toxicity bioassay with marine sediments. Chemosphere 54, 679-687.

OSPAR, 1992. OSPAR Convention for the Protection of the Marine Environment of the North-East Atlantic.

Peng, F., Liang, K.-M., Shao, H., Hu, A.-M., 2005. Nano-crystal glass-ceramics obtained by crystallization of vitrified red mud. Chemosphere 59, 899-903.

Peng, J.-f., Song, Y.-h., Yuan, P., Cui, X.-y., Qiu, G.-l., 2009. The remediation of heavy metals contaminated sediment. J. Hazard. Mater. 161, 633-640.

Pougnet, F., Schäfer, J., Dutruch, L., Garnier, C., Tessier, E., Dang, D.H., Lanceleur, L., Mullot, J.-U., Lenoble, V., Blanc, G., 2014. Sources and historical record of tin and butyl-tin species in a Mediterranean bay (Toulon Bay, France). Environ. Sci. Pollut. Res. 21, 6640-6651.
Prato, E., Biandolino, F., Libralato, G., 2015. A toxicity scoring system for the 10 days whole sediment test with Corophium insidiosum (Crawford). Environ. Monit. Assess. 187, 1-11.

Salomons, W., 1998. Biogeodynamics of contaminated sediments and soils: perspectives for future research. J. Geochem. Explor. 62, 37-40.

Saussaye, L., Hamdoun, H., Leleyter, L., van Veen, E., Coggan, J., Rollinson, G. Maherzi, W., Boutouil, M., Baraud, F., 2016. Trace element mobility in a polluted marine sediment after stabilisation with hydraulic binders. Mar. Pollut. Bull. 110 (1), 401-408.

Scanferla, P., Ferrari, G., Pellay, R., Ghirardini, A.V., Zanetto, G., Libralato, G., 2009. An innovative stabilization/solidification treatment for contaminated soil remediation: demonstration project results. J. Soils Sedimen. 9, 229-236.

Singh, A.P., Singh, P.C., Singh, V.N., 1993. Cyclohexanethiol separation from kerosene oil by red mud. J. Chem. Technol. Biotechnol. 56, 167-174.

Tabelin, C.B., Hashimoto, A., Igarashi, T., Yoneda, T., 2014. Leaching of boron, arsenic and selenium from sedimentary rocks: II. pH dependence, speciation and mechanisms of release. Sci. Total Environ. 473-474, 244-253.

Taneez, M., Hurel, C., Marmier, N., 2015. Ex-situ evaluation of bauxite residues as amendment for trace elements stabilization in dredged sediment from Mediterranean Sea: a case study. Mar. Pollut. Bull. 98, 229-234.

Taneez, M., Marmier, N., Hurel, C., 2016. Use of neutralized industrial residue to stabilize trace elements ( $\mathrm{Cu}, \mathrm{Cd}, \mathrm{Zn}, \mathrm{As}, \mathrm{Mo}$, and $\mathrm{Cr}$ ) in marine dredged sediment from South-East of France. Chemosphere 150, 116-122.

Tessier, E., Garnier, C., Mullot, J.-U., Lenoble, V., Arnaud, M., Raynaud, M., Mounier, S. 2011. Study of the spatial and historical distribution of sediment inorganic contamination in the Toulon bay (France). Mar. Pollut. Bull. 62, 2075-2086.

Van Wezel, A.P., 1999. Overview of International Programmes on the Assessment of Existing Chemicals.

Zhang, C., Yu, Z.-g., Zeng, G.-m., Jiang, M., Yang, Z.-Z., Cui, F., Zhu, M.-y., Shen, L.-q., $\mathrm{Hu}$, L., 2014. Effects of sediment geochemical properties on heavy metal bioavailability. Environ. Int. 73, 270-281. 